UDC 614.8: 351.74: 37.018 .46

I. V. KiRYEV, N. V. Zhabotynska, O. A. RYABova

National University of Pharmacy

\title{
METHODOLOGICAL APPROACHES TO TEACHING THE COURSE “THE FIRST RESPONDER” in The National University of Pharmacy
}

It is of particular relevance in Ukraine to train the police to provide the first aid before an ambulance crew arrives. The police are the first to arrive at the scene of the incident, and according to statistics, the first premedical aid provided within the first 4 minutes increases the chances of survivors by $30 \%$.

Aim. To share the experience of organizing the course "The First Responder" for officers of the National Police at the premises of the National University of Pharmacy (NUPh) and discuss the prospects for teaching this course to other categories of people who are obliged to provide the first premedical aid.

Materials and methods. To execute the Order of the Ministry of Health of Ukraine No. 346 dated 03.29.2017, training of 40 officers of the National Police of Kharkiv and the Kharkiv Region according to the program of the course "The First Responder" was organized in the NUPh. Five groups of 8 people each were formed. The course is designed for 48 hours for 1 week.

Results. $92.5 \%$ of police officers successfully completed the course with an average test control result of $90.3 \%$ and $78-91 \%$ when passing practical skills.

Conclusions. The high-quality organization of training on the course "The First Responder" and material and technical support allow the personnel of the National Police of Ukraine to master one of the professional competencies - the skill of providing the first premedical aid in extreme situations. It is extremely important and relevant for reducing the pre-hospital mortality rate before the ambulance crew arrives.

Key words: methodological approaches, organization of teaching, "First Responder" course; National University of Pharmacy (NUPh); police.

\section{I. В. КіреєВ, Н. В. ЖАБОТИНСЬКА, О. О. РЯБОВА}

Національний фармацевтичний університет

МЕТОДОЛОГІЧНІ ПІДХОДИ ДО ОРГАНІЗАЦІї ВИКЛАДАННЯ КУРСУ «ПЕРШИЙ НА МІСЦІ ПОДІї» В НАЦІОНАЛЬНОМУ ФАРМАЦЕВТИЧНОМУ УНІВЕРСИТЕТІ

В Україні особливої актуальності набуває навчання поліцейських навичкам надання домедичної допомоги до приїзду швидкої (екстреної) медичної допомоги, оскільки саме вони першими прибувають на місце події, а за статистикою, допомога, надана протягом перших 4 хвилин, збільшує шанси потерпілих на порятунок на $30 \%$.

Мета: узагальнення досвіду організації викладання курсу «Перший на місці події» для співробітників Національної поліції на базі НФаУ та обговорення перспектив викладання курсу для інших категорій осіб, які зобов'язані надавати домедичну допомогу.

Матеріали та методи. На виконання наказу МОЗ України від 29.03.2017 р. № 346 в НФаУ було організовано навчання за програмою курсу домедичної допомоги «Перший на місці події» для працівників Національної поліції. Для проходження курсу було направлено 40 співробітників Національної поліції м. Харкова та Харківської області, з яких сформовано 5 груп по 8 осіб у кожній. Курс розрахований на 48 годин протягом 1 тижня.

Результати. 92,5 \% поліцейських успішно закінчили курс із середнім результатом 90,3 \% під час тестового контролю та 78-91 \% під час складання практичних навичок.

Висновки. Високоякісна організація навчання на курсі та матеріально-технічне забезпечення дозволяють особовому складу Національної поліції України оволодіти однією з фахових компетенцій - здатністю надавати домедичну допомогу в екстремальних ситуаціях, що надзвичайно важливо й актуально для зменшення смертності постраждалих на догоспітальному етапі до приїзду бригади швидкої (екстреної) медичної допомоги.

Ключові слова: методологічні підходи; організація викладання; курс «Перший на місці події»; Національний фармацевтичний університет (НФаУ); поліцейські.

\section{И. В. КИРЕЕВ, Н. В. ЖАБОТИНСКАЯ, О. А. РЯБОВА}

Национальный Фармацевтический университет

МЕТОДОЛОГИЧЕСКИЕ ПОДХОДЫ К ОРГАНИЗАЦИИ ПРЕПОДАВАНИЯ КУРСА ЩПЕРВЫЙ НА МЕСТЕ ПРОИСШЕСТВИЯ» В НАЦИОНАЛЬНОМ ФАРМАЦЕВТИЧЕСКОМ УНИВЕРСИТЕТЕ

В Украине особую актуальность приобретает обучение полицейских навыкам оказания доврачебной помощи до приезда скорой медицинской помощи, поскольку именно они первыми прибывают на место происшествия, а по статистике, помощь, оказанная в течение первых 4 минут, увеличивает шансы пострадавших на спасение на 30 \%. 
Цель: обобщение опыта организации преподавания курса «Первый на месте происшествия» для сотрудников Национальной полиции на базе НФаУ и обсуждение перспектив преподавания курса для других категорий лиц, которые обязаны оказывать доврачебную помощь.

Материалы и методы. Для выполнения приказа МЗ Украины от 29.03.2017 г. № 346 в НФаУ было организовано обучение 40 сотрудников Национальной полиции г. Харькова и Харьковской области по программе курса доврачебной помощи «Первый на месте происшествия». Было сформировано 5 групп по 8 человек в каждой. Курс рассчитан на 48 часов в течение 1 недели.

Результаты. 92,5 \% полицейских успешно закончили курс со средним результатом тестового контроля 90,3 \% и 78-91 \% при сдаче практических навыков.

Выводы. Высококачественная организация обучения на курсе и материально-техническое обеспечение позволяют личному составу Национальной полиции Украины овладеть одной из профессиональных компетенций - умением оказывать домедицинскую помощь в экстремальных ситуациях, что является чрезвычайно важным и актуальным для уменьшения смертности пострадавших на догоспитальном этапе до приезда бригады скорой (экстренной) медицинской помощи.

Ключевые слова: методологические подходы; организация преподавания; курс «Первый на месте происшествия»; Национальный фармацевтический университет (НФаУ); полицейские.

Statement of the problem. Today, cardiovascular diseases occupy the first place in the absolute mortality rate of Ukraine, external causes, which include various traumas, are on the second place, and in persons of the working age traumas go to the first place [1]. Over the past 10 years, mortality from traumatism in Ukraine has increased by $38.7 \%$ [2]. In this case, $24 \%$ of the victims die in hospitals, and $76 \%$ - in the pre-hospital stage. In developed countries, on the contrary: $72 \%$ of the victims die in hospitals, and only $28 \%$ at the pre-hospital stage. [3]. Mortality in the first 15 minutes from the moment of injury is $35 \%$ [4]. According to the estimates of medical specialists, $20 \%$ of fatal cases at the pre-hospital stage were associated with the injuries incompatible with life, and the cause of other $80 \%$ was the imperfection of the system of providing emergency medical aid to the victims directly in the emergency area $[3,5]$. When considering mortality from cardiovascular diseases most people die as a result of coronary heart disease, which is the cause of severe cardiovascular events, including sudden death (when a person dies suddenly on the street, in public places, and the medical care is not given to this person in time) [6].

Considering the above, providing of the first premedical aid is of particular relevance, namely urgent actions and organizational measures aimed at saving a person's life in a state of emergency, minimizing the consequences of the impact of such a state on the health at the site of the event [7]. According to the preliminary data of scientists, in case when $10 \%$ of the working-age population is able to provide the first premedical aid, the mortality rate at the pre-hospital stage decreases by $20 \%$ [8].
According to statistics, the first premedical aid provided during the first 4 minutes increases the chances of survivors by $30 \%$ [9]. The police are the first to arrive at the scene. Therefore, teaching the police the skills to provide the first premedical aid before the arrival of an ambulance crew becomes of particular relevance.

Analysis of recent research and publications. In 2017, the Ministry of Health of Ukraine issued the Order "On the improvement of training on providing the premedical aid to people without medical education", and approved the training programs of three levels for training those persons who did not have medical education, but should provide the first premedical aid according to their official duties [10]. In 2018, the Order of the Ministry of Health of Ukraine approved the volumes of admission and graduation of persons for training to provide the premedical aid [11]. The National University of Pharmacy (NUPh) was included in the list of twenty-two higher educational institutions as an institution that would fulfill the State Order for training and advanced studies of persons to provide the first premedical aid.

Domestic scientists worked on the problem of organizing training on providing the premedical aid to the victims. The following tutorials were developed: "First premedical aid in extreme situations and medical protection of the population in emergencies" edited by Volyansky P. B. and Grinzovsky A. M. for preparation of specialists of the first (educational-professional) level, branch of knowledge 22 "Healthcare", specialty 227 "Physical therapy, ergotherapy" [12] and "Emergency and Immediate Medical Aid" edited by Hudyma A. A. [13]. Under the guidance of V. Krylyuk in the Training Department 
of the Ukrainian Scientific and Practical Center of Emergency Medical Care and Disaster Medicine, in cooperation with the All-Ukrainian Council for Resuscitation and Emergency Medical Assistance there is a training course to prevent or minimize the consequences of emergencies, reduce the number of victims from accidents and disasters, and improve the level of knowledge and skills in providing emergency medical and first premedical aid [14].

Identification of aspects of the problem unsolved previously. The discipline "First premedical aid" introduced into the curriculum of students of specialty 226 "Pharmacy, Industrial Pharmacy" is very well taught at higher education institutions, in particular in the NUPh. However, teaching the course "The First Responder" at the level of the State Order for people who do not have medical education, but must provide the first premedical aid according to their official duties is organized for the first time. Understanding of the problems arisen during the training and the experience of solving these issues may be useful for further organization of advanced training in providing the premedical aid to the wider population.

objective statement of the article. The aim of the article is to share the experience of organizing the course "The First Responder" for officers of the National Police at the premises of the NUPh, highlight the results of training, and discuss the prospects for teaching this course to other categories of people who are obliged to provide the first premedical aid.

Presentation of the main material of the research. In pursuance of the Order of the Ministry of Health of Ukraine No. 346 dated March 29, 2017 [10] the rector of the NUPh decided to organize training on the program of the course "The First Responder" for the staff of the National Police. In order to implement this decision it was necessary to work in several directions: training of the personnel, provision of the material and technical base and organization of the educational process.

In order to prepare the staff, the staff members of the Department of Pharmacotherapy doctors of the highest category of different specialties with many years of experience in teaching the discipline "First premedical aid" to the students of the NUPh were selected. Two associate professors of the Department headed by the head of the Department passed the thematic advanced training "Teacher-instructor" in the amount of 24 hours and "Instructor of the course "The First Responder" in the amount of 40 hours at the premises of the Simulation Training Center "TESIMED" - the structural unit of the Ternopil State Medical University - and received the corresponding certificates. These certificates in accordance with the Order of the Ministry of Health of Ukraine [10] allow them to teach the course "The First Responder". Five teachers of the Department passed the course "Basic life support" in the amount of 8 hours corresponding to the international standards of provision of emergency medical aid in case of violations or stopping of breathing, cardiovascular disorders and received certificates of the European Resuscitation Council.

For logistic support of the course "The First Responder" the equipment was purchased from the list of the minimum equipment required for the program calculated based on one group of eight students approved by the Order of the Ministry of Health of Ukraine [10]. In order to master the practical skills the medical simulator "Taras" was used (designed to teach the skills of providing the first premedical aid to the victims - indirect heart massage and artificial ventilation of the lungs), an educational automatic external defibrillator, a baby mannequin, Esmarch's Tourniquet and Combat Application Tourniquet ("C.A.T.") for stopping bleeding, nasopharyngeal and oropharyngeal air ducts of various sizes, an Ambu Bag, a barrier device for the mouth-to-mouth artificial ventilation of the lungs, cervical collars of various sizes, an individual dressing package with the elastic compression component and the moisture resistant protective sheath, elastic bandages, triangular scarves, flexible splint "SAM", medical gloves, a thermal blanket. The multimedia equipment was also provided: a laptop, a multimedia projector, and a screen.

40 officers of the National Police of Kharkiv and the Kharkiv Region were sent for the course "The First Responder". Five groups of 8 people each were formed. The course is designed for 48 hours for 1 week: 20 hours of lectures, 26 hours of practical classes, 2 hours for control of knowledge: 1 hour - test control, and 1 hour - a practical examination. The course instructors adapted the training 
course "The First Responder" taking into account the requirements of the Ministry of Health of Ukraine approved by the Academic Council of the NUPh, and the thematic plan of practical classes was developed.

Upon completion of the course, the students should have been able to identify and assess the breath by the "see-listen-feel" method in the victim with suspicion of sudden cardiac arrest; restore the passage of the respiratory tract by the manual method and by pushing the lower jaw to carry out pressing on the thoracic cell during the implementation of cardiopulmonary resuscitation in adults, children, infants; carry out artificial ventilation of the lungs in adults and infants; use an external automatic defibrillator during cardiopulmonary resuscitation; provide the victim with a stable position. All skills for providing the premedical aid were thoroughly practiced by each student during practical classes.

The control of theoretical knowledge was carried out using tests, practical skills - with the help of simulation tasks, which were assessed according to a special form developed by the Ministry of Health of Ukraine. In this form, the emphasis was on critical practical skills, which unfulfillment would have led to the death of the victim before the hospital stage. For unfulfillment of any of the critical practical skills no points were awarded.

$92.5 \%$ of police officers successfully completed the course with an average result of 90.3\% during the test control and 78-91\% when passing practical skills (successful completion of the course is possible only with at least $70 \%$ correct answers in the theoretical testing and during practical testing) [10]. Three police officers $(7.5 \%)$ were expelled from the course due to their absence more than $80 \%$ of class time (successful completion of the course is possible only when attending all lectures and practical classes [10].

Conclusions. Thus, more than $90 \%$ of police officers - students of the course "The First Responder" successfully completed it at the premises of the NUPh. The high-quality organization of training on the course "The First Responder" and material and technical support allow the personnel of the National Police of Ukraine to master one of the professional competencies - the skill of providing the first premedical aid in extreme situations, and it is extremely important and relevant for reducing the pre-hospital mortality rate before the ambulance crew arrives.

Prospects for further research. It is necessary to organize training on the course "The First Responder" for other persons who are obliged to provide the first premedical aid to a human in an urgent condition [6], in particular for the staff emergency rescue services, employees of the state fire brigade, pharmacists; conductors of passenger cars; flight attendants; other persons who do not have medical education, but by their official duties they must have practical skills in providing the first premedical aid.

Conflict of interests: authors have no conflict of interests to declare.

\section{References}

1. Смертність в Україні [Електронний ресурс]. - Режим доступу: https://uk.wikipedia.org/wiki/ (дата звернення 07.05.2019).

2. Філь, А. Ю. Поєднана травма тіла, підвищення виживання постраждалих. Стан проблеми (огляд літератури) / А. Ю. Філь // Літопис травматології та ортопедії. - 2014. - № 1/2. - С. 137-139.

3. Державна служба України з надзвичайних ситуацій [Електронний ресурс]. - Режим доступу: http://iducz.dsns.gov.ua/ua/Domedichna-dopomoga.html?PRINT (дата звернення 12.02.2019).

4. Надання допомоги потерпілим із політравмою при домінуючій торакоскелетній травмі / О. Л. Ковальчук, І. С. Кулянда, Ю. С. Сморщок, О. О. Кулянда // Шпитальна Хірургія. - 2011. № $4 .-$ С. 72-74.

5. Волянський, П. Б. Домедична допомога як складова сучасної системи реагування на надзвичайні ситуації [Електронний ресурс] / Волянський П. Б., Макаренко А. М. // Державне управління. Удосконалення та розвиток. - 2015. - № 12. - Режим доступу: http://www.dy.nayka.com. ua/?op=1\&z=931 (дата звернення 12.02.2019).

6. В Україні показники смертності через хвороби серця є одними з найвищих у світі [Електронний ресурс] // Укрінформ: мультимедійна платформа України. - Режим доступу: https://www. ukrinform.ua/rubric-culture/2544198-v-ukraini-pokazniki-smertnosti-cerez-hvorobi-serca-eodnimi-z-najvisih-u-sviti.html (дата звернення 12.02.2019). 
7. Про екстрену медичну допомогу [Електронний ресурс] : закон України // Відомості Верховної Ради. - 2013. - № 30 - Режим доступу: https://zakon.rada.gov.ua/laws/show/5081-17 (дата звернення 12.02.2019).

8. Знай! Вмій! Врятуй! [Електронний ресурс] // Міжнародний благодійний фонд «Допомоги постраждалим внаслідок дорожньо-транспортних пригод». - Режим доступу: http://dopomogadtp.com/ua/znaj-vmij-vryatuj/ (дата звернення 12.02.2019).

9. Допомога до приїзду швидкої: в Україні розпочалось навчання за програмою «Перший на місці події» [Електронний ресурс] // МОЗ України. - Режим доступу: http://moz.gov.ua/article/ news/dopomoga-do-priizdu-shvidkoi-v-ukraini-rozpochalos-navchannja-za-programoju-pershijna-misci-podii (дата звернення 12.02.2019).

10. Про удосконалення підготовки з надання домедичної допомоги осіб, які не мають медичної освіти [Електронний ресурс] : наказ МОЗ України № 346 від 29.03.2017. - Режим доступу: https://zakon.rada.gov.ua/rada/show/v0346282-17 (дата звернення 12.02.2019).

11. Обсяг прийому та випуску осіб з надання домедичної допомоги у 2018 році [Електронний ресурс] : наказ МО3 України № 1688 від 14.09.2018. - Режим доступу: http://moz.gov.ua/ uploads/1/7595-dn_20180914_1688_dod.pdf (дата звернення 12.02.2019).

12. Домедична допомога в екстремальних ситуаціях та медичний захист населення в надзвичайних ситуаціях : навч. посіб. / А. М. Гринзовський та ін. ; за заг. ред. П. Б. Волянського, А. М. Гринзовського. - Київ : ІДУЦЗ, 2018. - 216 с.

13. Екстрена та невідкладна медична допомога [Електронний ресурс] : підруч. для студ. вищ. навч. закл. МОЗ України / М. І. Швед та ін. - Тернопіль : Укрмедкнига, 2016. - 447 с. - Режим доступу: http://library.odmu.edu.ua/catalog/250909 (Date of access: 07.05.2019).

14. Архіви по тегам: домедична допомога [Електронний ресурс] / Тернопільський національний медичний університет ім. I. Я. Горбачевського. - Тернопіль, 2019. - Режим доступу: https:// www.tdmu.edu.ua/tag/domedychna-dopomoga/ (Date of access: 07.05.2019).

\section{References}

1. Smertnist v Ukraini [Mortality in Ukraine]. Retrived 07.05.2019 from https://uk.wikipedia.org/wiki/ [in Ukrainian].

2. Fil, A. Yu. (2014). Litopys travmatolohii ta ortopedii, 1/2, 137-139.

3. Derzhavna sluzhba Ukrainy z nadzvychaynykh sytuatsii [Ukrainian State Emergency Service]. iducz. dsns.gov.ua. Available at: http://iducz.dsns.gov.ua/ua/Domedichna-dopomoga.html?PRINT

4. Kovalchuk, O. L., Kulianda, I. S., Smorshchok, Yu. S., Kulianda, O. O. (2011). Shpytalna Khirurhiia, 4, 72-74.

5. Volianskyi, P. B., Makarenko, A. M. (2015). Derzhavne upravlinnia. Udoskonalennia ta rozvytok, 12. Available at: http://www.dy.nayka.com.ua/?op=1\&z=931

6. V Ukraini pokaznyky smertnosti cherez khvoroby sertsia ye odnimy z naivyshchykh u sviti [In Ukraine, mortality rates due to heart disease are among the highest in the world]. Ukrinform: multymediina platforma Ukrainy. Available at: https://www.ukrinform.ua/rubric-culture/2544198-v-ukrainipokazniki-smertnosti-cerez-hvorobi-serca-e-odnimi-z-najvisih-u-sviti.html

7. Zakon Ukrainy "Pro ekstrenu medychnu dopomohu". (2013). Vidomosti Verkhovnoi Rady, 30. Available at: : https://zakon.rada.gov.ua/laws/show/5081-17

8. Mizhnarodnyi Blahodiinyi Fond “Dopomohy postrazhdalym vnaslidok dorozhno-transportnykh pryhod". Znai! Vmii! Vriatui! Available at: http://dopomogadtp.com/ua/znaj-vmij-vryatuj/

9. MOZ Ukrainy. Dopomoha do pryizdu shvydkoi: v Ukraini rozpochalos navchannia za Prohramoiu "Pershyi na mistsi hodii". Available at: http://moz.gov.ua/article/news/dopomoga-do-priizdu-shvidkoi-v-ukraini-rozpochalos-navchannja-za-programoju-pershij-na-misci-podii

10. MOZ Ukrainy. (2017). Nakaz "Pro udoskonalennia pidhotovky z nadannia domedychnoi dopomohy osib yaki ne maiut medychnoi osvity" No. 346 vid 29.03.2017. Available at: https://zakon.rada.gov.ua/ rada/show/v0346282-17

11. MOZ Ukrainy. (2018). Nakaz "Pro obsiah pryiomu ta vypusku osib z nadannia domedychnoi dopomohy" No. 1688 vid 14.09.2018. Available at: http://moz.gov.ua/uploads/1/7595-dn_20180914_1688_dod.pdf

12. Hrynzovskyi, A. M., Volianskyi, P. B., Kalashchenko, S. I. (2018). Domedychna dopomoha v ekstremalnykh sytuatsiiakh ta medychnyi zakhyst naselennia $v$ nadzvychainykh sytuatsiiakh [Premedical aid in extreme situations and medical protection of the population in emergency situations]. Kyiv: IDUTsZ.

13. Shved, M. I., Hudyma, A. A., Heriak, S. M. (2016). Ekstrena ta nevidkladna medychna dopomoha [Urgent and emergency medical care]. Ternopil: Ukrmedknyha. Available at: http://library.odmu.edu. ua/catalog/250909 
14. Ternopilskyi natsionalnyi medychnyi universytet im. I. Ya. Horbachevskoho. (2019). Arkhivy po teham: domedychna dopomoha [Tag archives: Premedical aid]. Ternopil. Available at: https://www. tdmu.edu.ua/tag/domedychna-dopomoga/

Information about authors:

Kiryev I. ., Doctor of Medicine (Dr. habil), professor, head of the Department of Pharmacotherapy, National University of Pharmacy (https://orcid.org/0000-0002-5413-9273).E-mail: ivkireev@ukr.net

Zhabotynska N. V., Candidate of Medicine (Ph.D.), associate professor of the Department of Pharmacotherapy,

National University of Pharmacy (https://orcid.org/0000-0003-3744-4927). E-mail: bronkevih@gmail.com

Ryabova O. O., Candidate of Medicine (Ph.D.), associate professor of the Department of Pharmacotherapy,

National University of Pharmacy (http://orcid.org/0000-0001-6716-0808). E-mail: oksanaroa@ukr.net

Відомості про авторів:

Кіреєв I. B., доктор медичних наук, професор, завідувач кафедри фармакотерапії, Національний фармацевтичний університет (https://orcid.org/0000-0002-5413-9273). E-mail: ivkireev@ukr.net

жаботинська $\boldsymbol{H}$. B., кандидат медичних наук, доцент кафедри фармакотерапії, Національний фармацевтичний університет (https://orcid.org/0000-0003-3744-4927). E-mail: bronkevih@gmail.com

Рябова О. О., кандидат медичних наук, доцент кафедри фармакотерапії, Національний фармацевтичний університет (http://orcid.org/0000-0001-6716-0808).E-mail: oksanaroa@ukr.net

Сведения об авторах:

Киреев И. В., доктор медицинских наук, профессор, заведующий кафедрой фармакотерапии, Национальный фармацевтический университет (https://orcid.org/0000-0002-5413-9273). E-mail: ivkireev@ukr.net

жаботинская $\boldsymbol{H}$. B., кандидат медицинских наук, доцент кафедры фармакотерапии, Национальный фармацевтический университет (https://orcid.org/0000-0003-3744-4927). E-mail: bronkevih@gmail.com

Рябова O. A., кандидат медицинских наук, доцент кафедры фармакотерапии, Национальный фармацевтический университет (http://orcid.org/0000-0001-6716-0808). E-mail: oksanaroa@ukr.net 